Israeli and international scholars and students rely on them in their studies of Israeli politics and society and continue to do so.

Asher Arian authored and coauthored dozens of books and articles on Israeli government and politics, elections, public opinion, and political behavior that were published in the major journals and academic presses in English and in Hebrew. Although most of his studies focused on the general public, he thought of politics as elite politics. His most influential books were Hopes and Fears of Israelis: Consensus in a New Society; The Choosing People: Voting Behavior in Israel; Security Threatened: Surveying Israeli Opinion on Peace and War; his textbook (published in three editions) Politics in Israel: The Second Generation; and the 13 volumes of The Elections in Israel series.

Asher Arian moved between the United States and Israel in his professional and personal life. He was born in Cleveland in 1938, received his Bachelor of Arts degree from Western Reserve University in 1961 and a doctorate in political science from Michigan State University in 1965. In 1966, he made "Aliya" to become the founding chair of the political science department and one of the founding fathers of the social sciences faculty at Tel Aviv University. Since the late 1980 s, together with his spouse Carol, he divided his time between the United States and Israel and held joint appointments at the Graduate Center of the City University of New York (CUNY) and the University of Haifa and the Israel Democracy Institute. Without doubt, the center of his life and academic career was Israel. Israel was his major field of research, and his family lives there: three children and seven grandchildren. He was an involved citizen and an astute observer of Israeli society and politics; his opinion was sought after by academics, politicians, and journalists.

Asher was loved and admired by generations of students and research associates, whom he loved to mentor and foster; many of them became his friends. His fight against cancer in his last years was courageous and stubborn. He continued to work relentlessly until the very last days. His most recent article "The Election Compass: Party Profiling and Voter Attitudes" (co-authored with Andre Krouwel, Mark Paul, and Raphael Ventura), will be published in the The Elections in Israel-20o9, which he co-edited with Michal Shamir.
Asher was fun to be with: his wisdom and good sense, his wit and humor, his compassion-widely conferred, though selective-touched the lives of many. The loss of Asher is thus both private and public. It is a personal loss to so many of us-family, friends, colleagues, and students. And it is a great loss to the profession, upon which he left such a significant imprint since he came to Israel almost 45 years ago and where he stayed until his very last days.

Michael Shamir
Tel Aviv University
Ranan Kuperman
University of Haifa

\section{ROBERT V. DANIELS}

Robert V. ("Bill") Daniels died in Burlington, Vermont, on March 28, 2010, at the age of 84 . He was a distinguished scholar and teacher at the University of Vermont for more than three decades, a respected administrator in various university positions, a president of the American Association for the Advancement of Slavic Studies, and an elected state senator in the Vermont legislature for nearly a decade. He authored two dozen books on themes of fundamental importance, mostly on revolution and modernization, power and authority, leadership and opposition, participation and bureaucracy, representation and communication, and ideology and culture in the Soviet Union.

The present writer did not know Daniels well but has long esteemed the man and his work. Bill's colleagues can expound on his energy, integrity, generosity, loyalty, and other personal qualities. Here is a tribute to his intellectual curiosity, creativity, acuity, productivity, and legacy to political history.

Daniels was a lifelong student of tsarist Russia, Soviet Russia, and post-Soviet Russia. He focused on "Russian national politics and political thought, the realm most crucial in shaping the destiny of the Soviet peoples." Daniels described policymaking and implementation in the Soviet Union and reconstructed motives and beliefs of Soviet leaders and oppositionists. Moreover, he explained changing functions of ideology and bureaucracy and compared Soviet political and social development with worldwide and long-term patterns of revolution and modernization. His arguments were inductive and deductive and his evidence was qualitative and quantitative. A historian by discipline, he was a political scientist by trade.

\section{Major Books}

Daniels's first and last books and documentary history are exceptionally important. The Conscience of the Revolution: Communist Opposition in Soviet Russia (1960) is a classic in Soviet studies. It is still the most authoritative and comprehensive analysis of the Bolshevik Party factions that were less authoritarian than the party leadership and unsuccessfully opposed many decisions and decision-making processes from 1917 to the mid-1930s. Daniels contended that "the Left Opposition" and "the Right Opposition" suffered "an unmitigated series of defeats at the hands of an apparently omnipotent party organization." Opposition movements "failed" because "at each critical juncture, the Opposition displayed vacillation, disunity, tactical obtuseness, and organizational ineptness," which were "traceable to a deeper defect: the Opposition lacked the necessary vision or self-consciousness about what it was and where it wanted to go." This thesis is clearly formulated, empathically developed, and meticulously documented.

The Rise and Fall of Communism in Russia (2007), Daniels's excellent last book, is a tightly integrated collection of his best essays on Soviet political history and its Russian antecedents and legacies. The stimulating introduction was commissioned by the Russian Academy of Sciences and is subtitled "Revolution, Modernization, and Socialism-Baselines of Modern Russian History." The book's topics include the origins of Marxism and Leninism in Russia, the Bolshevik revolution, Stalinization and Stalinism, Nikita Khrushchev's authoritarian populism, Leonid Brezhnev's bureaucratic ossification, and Mikhail Gorbachev's "ill-fated reforms." The final chapter is a rejoinder to critics of Sovietology for its alleged "failure" to foretell the collapse of the Soviet Union and the Soviet bloc. This thoughtprovoking and wide-ranging volume is an ideal core text for graduate and undergraduate courses on Russian and Soviet politics and history in the twentieth century.

Daniels's third outstanding book is $A$ Documentary History of Communism in Russia: From Lenin to Gorbachev (1993), which is complemented by A Documentary History of Communism and the World: From 
Revolution to Collapse (1994). These anthologies are invaluable for both scholars and students. Daniels masterfully winnowed, selected, edited, introduced, annotated, and translated abundant primary source documents that feature programmatic debates and policy pronouncements. One is hardpressed to identify more than a few important documents omitted in the anthology on Russia, especially in its extensive sections on Lenin and Stalin. Daniels's introductory essay includes penetrating analyses of the theory and practice of Leninism, Stalinism, and their roots and legacies. He explains the motivational impact of Marx's "doctrine of inevitability" and underscores the importance of the non-Marxist Russian revolutionary tradition, from which Lenin drew insight and inspiration about political organization, mobilization, violence, pedagogy, and "the moral imperative of revolution."

The most notable other books by Daniels include The End of the Communist Revolution (1993), which analyzes Soviet history in reverse chronological order; Russia: The Roots of Confrontation (1985), which surveys tsarist and Soviet Russian history with alternating chapters on domestic politics and foreign policy; and Red October: The Bolshevik Revolution of 1917 (1967; reprinted 1984), which details the activities of Bolshevik Party leaders in 1917 and their decision to seize power.

\section{Revolution}

Daniels underscored the idea that "revolution is not an event, it is a process." The revolutionary process is "prolonged," "complex and multidimensional," and "deeply embedded in the historical evolution of a given society." This process has both "objective" and "historically indeterminate" components. Revolution "breaks out and proceeds in stages that are basically independent of the will of individual revolutionaries," their "illusion" of power notwithstanding. But the predilections and predispositions of revolutionary leaders, especially their perceived options and calculated actions, can greatly influence the beginning and ending of a revolution.

Significantly, Daniels contended that Russia has been in a revolution since 1905 and that stages in "the life cycle of the Russian revolution" have followed a pattern common to revolutions in all countriesfor example, seventeenth-century England; eighteenth- and nineteenth-century France; and twentieth-century China, Germany, and Spain. He saw many variations within stages of revolutions, but not in their number, nature, or sequence.

According to Daniels, the five universal stages of revolution and their Russian counterparts are:

1. Moderate reform: the 1905 revolution, the 1917 February revolution, and the Provisional Government (1905-17)

2. Extremist takeover: War Communism and civil war (1918-21)

3. Thermidorean reaction: the New Economic Policy (1921-28)

4. Postrevolutionary dictatorship: Stalin's socialist revolution (1928-34), Stalin's imperial restoration (1934-53), and neoStalinism (1953-85)

5. Moderate revolutionary revival: Mikhail Gorbachev (1985-91), Boris Yeltsin (1987-99), Vladimir Putin (2000-08), and Dmitri Medvedev (2008-present)

These stages of revolution follow traditional interpretations up to the final stage, at which point Daniels makes creative modifications. His comparative analysis of revolutions led him to expect that "moderate revolutionary revival" would "cleanse" and develop the initial "moderate reform." From October 1905 to February 1917, "moderate reform" included a short-lived workers council, quasi-constitutional monarchy, and dissolvable multiparty parliaments (i.e., the St. Petersburg Soviet, October Manifesto, and four Dumas). From February 1917 to January 1918, "moderate reform" included the Petrograd Soviet and nationwide soviets, Provisional Government and independent Duma, "socialist" and "bourgeois" parliamentary and mass political parties, and elections to a Constituent Assembly that was immediately and forcibly disbanded by the Bolsheviks.

Daniels emphasized that power struggles in a "moderate revolutionary revival" can create "indeterminate crisis situations," and that diverse outcomes can result from such situations. From 1987 to 1991, Gorbachev's "leftist" revolution (for constitutional socialist democracy) and Yeltsin's "rightist" revolution (for populist market democracy) clashed with mounting intensity, as did both democratic revolutions with a conservative counterrevolution (for neoStalinist communist authoritarianism).

Quite probably, Daniels believed that conservative communists fragmented the party, the political system, and the Soviet Union unintentionally, but "rightist" democrats did so intentionally, thereby wasting an unprecedented opportunity to fulfill the promise of "moderate reform" (1905-17) and to end the century-old Russian revolution. By subverting "moderate revolutionary revival" in the entire U.S.S.R., "rightist" democrats, as well as conservative communists, prolonged or heightened authoritarianism and delayed or derailed modernization in most of the USSR's successor states, including Russia.

\section{Modernization}

Daniels conceptualized modernization as a multifaceted process-"the emergence of a pattern of life based on science, literacy, industrialization, urbanization, and secularization"-which progresses in three stages:

1. Government promotion of trade, industry, and technology

2. Individualist capitalism and laissezfaire doctrine

3. Organized capitalism and large corporations

The interplay between stages of revolution and stages of modernization was of particular interest to Daniels. He observed mounting "pressures and movements" for systemic change after Brezhnev's "era of stagnation." He foresaw volcanic interaction among political-administrative ossification, socioeconomic evolution, and scientific-technological revolution. He spotlighted the rifts between ideology and reality, especially in the entrepreneurial and corporate stages of modernization and the neo-Stalinist "postrevolutionary dictatorship" and "moderate revolutionary revival." He contrasted the slow, measured, and rapid change in cultures, institutions, and technologies, respectively. And he examined how tangible features of revolution and modernization interact not only with one another, but also with intangible conceptions and evaluations of political actors.

Daniels vigorously disputed claims that the Soviet political system was incapable of fundamental change because of its ontological, structural, ideological, cultural, or moral "essence." From his perspective, "the system that collapsed in 1991 was vastly different from the one that the Bolsheviks had attempted to put in place in 1917. It had gone through all the stages of the revolutionary process and had been shaped 
both by the Russian historical legacy and by the challenges of modernization. What changed least was the framework of ideological legitimation to which successive Communist leaders clung, giving the illusion of continuity to a history of deep flux."

In 1981, at the end of the Brezhnev era, Daniels reconstructed the "dilemma" of modernization as perceived by moderate reformist and conservative leaders: "How to derive advantages from high technology and educated manpower in the form of economic and military power, without making concessions with respect to decentralization of initiative or special-interest values that might compromise the essential principle of control and goal-setting from the top?" Resolution or reformulation of this "dilemma" was urgently needed, Daniels warned: "When the irresistible force of socioeconomic change meets the immovable object of autocratic government, one has the makings of a revolutionary situation. Will the new leadership be of such a mind as to entertain the more fundamental reforms that seem essential in order to avert such a potential collision?"

Daniels viewed the political system bequeathed to Gorbachev as an unstable hybrid: "The confluence of socioeconomic modernization and political-administrative immobilism has given a distinctive form to the evolving Soviet system, though it is hard to categorize. It is neither despotic nor free, neither totalitarian nor pluralistic, but a curious amalgam of functional interests and technical imperatives embedded in a commitment to the monopoly of power."

\section{Totalitarianism and Pluralism}

Daniels acknowledged that elements of totalitarianism persisted throughout the post-Stalinist era not only in official ideology, but also in state-society relations. In 1985, he observed: "The Soviets still have no concept of constitutional or legal restraints on those who rule.... In terms of citizens' rights, as in the workings of the power structure, there has been little evolution in principle away from the totalitarian model of Stalinism."

But there were large and small gaps between the theory and experience of totalitarianism, Daniels argued. The totalitarian model "did not allow for either the complex development or the ultimate dissolution of the totalitarian state," and it "erred further by not taking sufficient account of the changes wrought in Soviet society under the totalitarian regime, including industrial growth, urbanization, and mass education." He noted "how clumsily, erratically, and inefficiently totalitarian controls functioned at the everyday level of Soviet life," even during Stalin's "socialist revolution" and "imperial restoration." And he amply documented that Khrushchev's and Brezhnev's oligarchies were much less totalitarian than Stalin's autocracy and that Gorbachev's nascent socialist democracy was, in principle if not in practice, post-totalitarian or nontotalitarian.

Daniels discerned weaknesses as well as strengths in pluralist approaches that vied with the totalitarian model: "Power centers of the Soviet bureaucracy-the military, the police, the industrial chiefs, the scientists and academics, the regional organizations of the party, and so forth-all have distinctive interests, and they no doubt lobby for their points of view within the councils of the party. Interest group politics may be particularly important during a succession phase, when the direction of the top party leadership is unclear. On the other hand, it would be highly misleading to equate Soviet interest group politics with the free-wheeling interplay of economic, ethnic, professional, and geographical interests in the U.S. system of representative government. All of the competing interests in the Soviet system are parts of one vast bureaucratic structure, subject to the dictates of the Communist Party leadership."

\section{Participatory Bureaucracy: Model and Concepts}

Daniels scrutinized the changing structure, composition, and operations of the Communist Party, especially its top policymaking bodies: the Central Committee of the CPSU (Communist Party of the Soviet Union), with several hundred members holding important party and state positions and convening in biannual plenums; an executive body of the Central Committee, the Politburo, with about a dozen members holding the most important party and state positions; another executive body of the Central Committee, the Secretariat, with about a dozen members holding the most important party positions, including the general secretary, the top position in the Soviet system; and the Central Committee apparatus, with about two dozen departments overseeing regional party organizations and state ministries, committees, and soviets (councils). Daniels observed that the most powerful leaders were members of both the Secretariat and the Politburo, and that these Secretariat members had sometimes disempowered the Politburo to "nothing but a sounding board."

Daniels constructed an original model of the post-Stalin political system. He conceptualized the whole system as a "participatory bureaucracy," in which the main components were "the circular flow of power" in the CPSU and "functional and territorial representation" in the Central Committee of the CPSU. He viewed the Central Committee as either the structural foundation or the communication hub of the system, and he distinguished between a "circular flow of power" that the general secretary either controlled or did not control. Daniels illustrated the uses of these concepts as follows:

Viewed according to the model of participatory bureaucracy, the Central Committee of the CPSU was the keystone of the entire Soviet system. In its makeup the Central Committee represented all the constituent elements of the Soviet power structure, both functionally and geographically. Its sessions provided the country's only ongoing broad-based policy forum. Finally, it constituted the primary institutional counterweight to individual bureaucratic dictation in the Stalinist fashion. In short, it was the Central Committee that allowed the bureaucracy to be participatory.

Participatory bureaucracy meant that the post-Stalin policymaking process had become complex and open-ended. All manner of influences-information, advice, recommendations, problems, complaintsmust flow upward, or else the top leadership cannot make the informed decisions on which the life of the entity depends. The problems of managing a complex economy based on modern technology made it abundantly clear to the Soviet leaders that they had to allow this reverse stream of influence to flow freely; their main concern was that the flow be kept within the organizational structure of the Communist Party.

The circular flow of power was a behindthe-scenes system of political control. The general secretary controlled appointments down through the party apparatus. In turn, his men manipulated the local committees and conferences of the party and the nominal election of representatives to the higher party bodies and the national party congress. Finally, the Central Committee, 
installed by each congress according to prearranged lists, ratified the co-optation of the topmost leaders to the Politburo and Secretariat. This closed the circuit by which the general secretary assured his own dominance.

The general secretary can lose control of the circular flow of power. His political enemies can break into the political circuit at the level of the Secretariat and use the power of appointment against him in the same way he had used it himself earlier.... When the appointment power was wrested from the general secretary, real control did not pass to the top leader but flowed instead from the top collective bodies around through the party organization. And the party apparatus simply followed the old practice of the circular flow and orchestrated conferences, elections, and patronage.

One can view the Central Committee as a well-defined and quite stable set of leading job slots whose occupants enjoy the elite status conferred by Central Committee membership as long as and only as long as they occupy their respective offices. The Soviet elite identified by membership in the Central Committee is chosen according to a set of unannounced rules that display a fine and complex sensitivity to a variety of interlocking status relationships... Through the principle of representation in the Central Committee, the various functional bureaucracies in the Soviet system and the local branches of the major ones had a voice or at least an ear in the central councils of the decisionmaking process. The evident rules of apportionment, representation, and ticket balancing that governed the makeup of the body lend considerable substance to the "interest group" approach to Soviet politics. But the whole social system in the USSR was organized under governmental bureaucratic structures, all of which were subsumed and integrated through the central and local committees of the Communist Party.

\section{Participatory Bureaucracy: Change and Continuity}

Stalin created "the circular flow of power" in the early 1920 s to control personnel appointments, cadre promotions, and facade elections at all levels of the party hierarchy. Daniels elaborated: "Through the circular flow of power-de facto down through the secretaries and over to the membership, de jure up through the party's conference and committee structure, Sta- lin brought the whole party under the bureaucratic control of the Secretariat. Through the party, he had ultimate control of the government at every level."

Khrushchev used "the circular flow of power" to his advantage in 1957 , when a Politburo majority tried to oust him. He insisted that the Central Committee had elected him, and that only it had the authority to retain or dismiss him. The Central Committee supported Khrushchev at a hastily convened plenum, and his appointees in the Central Committee not only preserved the power of their benefactor, but also enhanced the power of their organization. In 1964, however, "the circular flow of power" worked to Khrushchev's disadvantage. He was ousted by a unanimous Politburo and Central Committee. The groundwork had been laid four or five years earlier, when Khrushchev lost his patronage power to conservative rivals in the Politburo and Secretariat. Khrushchev's removal was a "watershed" in Russian history, Daniels affirmed.

The established leader of the country was removed by the rules of representative procedure, and it follows that the successor leadership would be removable in the same way.... The top leader was only a representative of the Central Committee, at most first among equals, and his tenure of leadership depended on the support of that group.... By making the succession to the leadership depend on the confidence of the Central Committee, Soviet political practice took a long step toward a sort of miniature parliamentary system at the top of the great bureaucratic pyramid of the party.

Brezhnev's "collective leadership" trumpeted its "trust in cadres." Ramifications were elucidated by Daniels: "The circular flow of power slowed down, job-tenure membership in the elite was confirmed, and participatory bureaucracy brought the status-quo interests of the upper officialdom strongly into the policymaking process. Moreover, there was only limited opportunity for natural leadership replacements, given the median age of the Central Committee in 1966 of only fifty six. All the unwritten rules of Soviet politicspromotion tracks, representational entitlements, rights to status, and the balance of function and prestige-were deeply confirmed."

Gorbachev's patron, Yuri Andropov, resumed the "the circular flow of power" when he became general secretary after
Brezhnev's death in 1982, and Gorbachev accelerated the "flow" after succeeding Konstantin Chernenko as general secretary in 1985. Gorbachev replaced many conservative party and state officials and expanded perestroika, glasnost, and democratization. But, as Daniels observed, "the pace of his economic reform and the reality of the new political culture have proved too much for the party bosses, perhaps even the new ones. The apparatus is in revolt against him, and he has lost control of the circular flow. This has forced him to look for a new basis of power, and he shifted to a fundamentally new cultural base for his rule-the Westernized intelligentsia, with its traditions of openness, creativity, and cosmopolitanism."

In September 1991, one month after the aborted conservative putsch, Daniels contrasted the "revolution of rising expectations" of the growing professional and educated class (including "the Westernized intelligentsia") and the "corrupt indifference and immobilism on the part of an aging Stalinist and neo-Stalinist leadership" (including party and state officials at all levels). Daniels cautioned: "Here was the old recipe for revolution, as the Soviet system sowed the seeds of its own destruction." Three months later came the actual destruction, which Daniels termed "the grand surprise."

\section{Collapse and Sovietology}

Could and should Sovietologists have foreseen or foretold the "collapses" or "breakups" of the Soviet Union and the Soviet bloc? Daniels' response was a clearly reasoned and strongly voiced "no!"

The "collapse" of the Soviet Union was "a complex, step-by-step, and still incomplete process of change" that was launched by "a sequence of events at the political center, inherently unpredictable, that eviscerated the authority and legitimacy of the Communist Party dictatorship," Daniels affirmed in 2007. "What came nearest to an abrupt collapse was the ideological rationale of official Marxism-Leninism, but this had long since turned into a mere liturgical façade.... Russian nationalism and great-power pride was the real ideology of the Communists, and this mentality persists virtually unabated along much of the political spectrum in Russia."

The "collapses" of the Soviet Union and the Soviet bloc were "governed" by personalities and contingencies, Daniels argued. $\mathrm{He}$ focused primarily on top leaders' 
perceptions and calculations and secondarily on ordinary citizens' expectations and frustrations. But he highlighted the indeterminate trajectories and unexpected outcomes of decisions and the coincidental sequences and improbable conjunctions of events. And he stressed that these clusters of factors constantly interacted and frequently clashed.

In Daniels's view, crucial specifics were the personal hostility between Gorbachev and Yeltsin, which Yeltsin initiated and escalated to undermine Gorbachev's leftist "moderate revolutionary revival"; the "Soviet tolerance of the overthrow of Communist rule in Eastern Europe," which unfettered national independence aspirations in the Russian, Ukrainian, and Baltic republics; and the need for "more statesmanship in all quarters," which might have established a "democratized Union" based on federal principles. He noted, "the breakup of the Soviet Union was above all a failure of federalism."

Sovietologists "were remarkably accurate and insightful in defining the elements of the crisis that overtook the Soviet Union," Daniels opined. "Their judgments went as far as any social science scholarship could responsibly go without resorting to wild guesswork. What could not be accurately foreseen, in the nature of the matter, was how these elements of crisis would play out at the political level where decisions by leading personalities and the effects of chance events could be decisive."

The totalitarian model "distorted the appraisal of Soviet reality" and embraced the axioms of anti-Soviet ideology, Daniels underscored. "Perhaps the greatest fault that can be retroactively attributed to Sovietology was to overestimate grossly the strength of the Soviet bloc, in its physical and economic capabilities as well as in its political cohesion and its psychological stamina. Much of this error resides in the unhistorical totalitarian model and its ideological corollaries."

Daniels concluded that the "collapses" of the Soviet Union and the Soviet bloc "could not have been closely predicted from any model or precedent. Historians should be able to understand this truth better than those social scientists who try too hard to make events appear to be law-governed. What happened was just as surprising to all the political actors in the Soviet Union and Eastern Europe as it was to observers in the outside world."

\section{Kudos}

For more than six decades, Daniels analyzed the causes, contents, and consequences of Soviet political development and enriched Western comprehension of the inner workings of the Communist Party. He contributed to and benefited from theoretical, comparative, interdisciplinary, and historical studies on many significant themes. One need not agree with all of Daniels's conclusions to appreciate his original concepts, abundant insights, cogent arguments, fresh evidence, and lucid writing. His legacy includes seminal scholarship, which is synthesized in The Rise and Fall of Communism in Russia.

In a word, Bill Daniels was an exceptionally inquisitive, innovative, and incisive Sovietologist-one of the best of the best.

Erik P. Hoffmann State University of New York at Albany

\section{MELVIN J. HINICH}

Mel Hinich, professor of political science and economics at the University of Texas at Austin and Mike Hogg Professor of Local Government, died in a tragic fall the evening of September 6, 2010.

Melvin J. Hinich achieved an international reputation in four academic disciplines: economics, engineering, political science, and statistics. He published pathbreaking contributions in seven books and more than four hundred journal articles, ranging over 40 years, with an endless energy for work and a childlike curiosity about the science of almost everything. Hinich's scholarship blended technical virtuosity, theoretical depth, interdisciplinary sweep, and a keen eye for the main chance in terms of substantive importance. But Mel was not simply a bright but easily distracted scholar with many interests. Rather, he was a scientist, a scholar who found most problems interesting, and he was capable of making connections across fields because so many problems share a deep logical and mathematical structure.

Mel received a BS and an MS in mathematics from the Carnegie Institute of Technology in 1959 and 1960, respectively. He earned his Ph.D. in statistics from Stanford University in 1963, working under Dr. Herman Chernoff. His thesis project involved the problem of estimating the properties of a recurring but unknown waveform in Gaussian data, and it proved useful enough to have the central theoretical result serve as the basis for a variety of civilian and military applications in signal processing.

Hinich began his academic career with the Graduate School of Industrial Administration at the Carnegie Institute of Technology in September 1963. He then circulated between academic teaching, research posts, and stints in settings where he could apply his knowledge to industrial and governmental uses. He held positions at the Bell Laboratories, the Columbia University-Hudson Laboratories, the Center for Naval Analyses, and the Naval Coastal Systems Center. His academic appointments have been at Carnegie Mellon University in the Graduate School of Industrial Administration, the School of Urban and Public Affairs, and the department of statistics. He moved to Virginia Polytechnic Institute as a professor of economics in 1974 and then to the University of Texas as a professor of government and economics in 1983. He also served as a research professor in the Applied Research Laboratories at UT-Austin, a position he loved because he was in close contact with scholars from different disciplines.

Mel's impact is easily illustrated both quantitatively and qualitatively. His work has been cited more than five thousand times in the professional literature, with 20 different papers and books in economics, political science, signal processing, and statistics all having received more than one hundred references. No one paper and, in fact, no one disciplinary contribution are the "main" result. Mel's contributions were broad and deep.

Qualitatively, Mel colleagues recognized his work by naming him to numerous honors and memberships in honorary societies. He was named Fellow of the Institute of Mathematical Statistics in 1973, appointed the Sherman-Fairchild Distinguished Scholar at the California Institute of Technology in 1975, named a Fellow of the Public Choice Society in 1988, elected president of that society in 1992, and named a Fellow of the American Statistical Association in 2002. Most recently, in 2008 , Mel was named one of the 21 original Fellows of the Society for Political Methodology.

\section{Scholarly Works}

Mel's scientific contributions were so sweeping that we can only summarize 